\title{
Isolates as models to study bacterial ecophysiology and biogeochemistry
}

\author{
Åke Hagström ${ }^{1, *}$, Farooq Azam ${ }^{2}$, Carlo Berg ${ }^{1}$, Ulla Li Zweifel ${ }^{3}$ \\ ${ }^{1}$ Department of Biology and Environmental Science, Linnaeus University, 39182 Kalmar, Sweden \\ ${ }^{2}$ Marine Biology Research Division, Scripps Institution of Oceanography, University of California, San Diego, La Jolla \\ CA 92093-0202, USA \\ ${ }^{3}$ Swedish Institute for the Marine Environment, Gothenburg University, Box 260, 40530 Goteborg, Sweden
}

\begin{abstract}
Here, we examine the use of bacterial isolates growing in artificial media or seawater as a means to investigate bacterial activity in the upper ocean. The discovery of a major role of bacteria in the ocean's carbon cycle owes greatly to the development of culture-independent assemblage-level approaches; however, this should not detract from the recognition of model isolates as representing the environmental microbiome. A long-established tool for culturing bacteria, in medicine and general microbiology, has been agar plates. In addition, a great variety of liquid substrates including seawater have been used to successfully identify and cultivate important bacteria such as Pelagibacter ubique. Yet, the discrepancy between microscopic counts and plate counts, the great plate count anomaly, has led to a biased perception of the limited relevance of isolated bacteria. Linking isolates to whole-genome sequencing, phylogenetic analysis and computational modeling will result in culturable model bacteria from different habitats. Our main message is that bacterial ecophysiology, particularly growth rates in seawater, and functionalities inferred through the identity, abundance and expression of specific genes could be mechanistically linked if more work is done to isolate, culture and study bacteria in pure cultures. When we rally behind a strategy aimed at culturing targeted phenotypes, we are not saying that cultureindependent studies of bacteria in the sea are not informative. We are suggesting that culturebased studies can help integrate the ecological and genomic views.
\end{abstract}

KEY WORDS: Bacteria $\cdot$ Culture $\cdot$ Physiology

\section{INTRODUCTION AND HISTORICAL BACKGROUND}

Marine microbiology has undergone major advances during the past 4 decades due to progress in techniques to observe and culture bacteria and further through the application of molecular methods (Temperton \& Giovannoni 2012). However, fundamental questions on in situ growth physiology and viability remain unresolved in part because of a lack of consensus towards a conceptual framework on

${ }^{*}$ Corresponding author: ake.hagstrom@lnu.se bacterial life strategies and in part because of a lack of suitable model organisms to study environmental bacterial physiology.

\section{Ocean surface water as a substrate for bacteria}

In retrospect, it is remarkable that until the end of the 1970s, it was thought that bacteria in the ocean could not grow in unenriched seawater (Jannasch 1979). This view was challenged through direct

() The authors 2017. Open Access under Creative Commons by Attribution Licence. Use, distribution and reproduction are unrestricted. Authors and original publication must be credited. 
demonstration to the contrary (Ammerman et al. 1984). As a result, bacterial seawater cultures (SWCs) were established, and conditions and prerequisites for marine bacteria to grow in seawater were described in 2 studies (Ammerman et al. 1984, Hagström et al. 1984). On the basis of these studies, it became commonplace to grow bacteria in filtered seawater (Li \& Dickie 1985). These SWCs enabled the measurement of growth yield and became useful as a bioassay of bioavailable dissolved organic carbon (DOC) (Zweifel et al. 1993). Also, as a special case, SWCs were used as dilution to extinction cultures for isolation and enumeration of marine oligotrophic bacteria, including the SAR11 clade (Button et al. 1993, Rappé et al. 2002, Simu et al. 2005).

Today, it is widely accepted that the most common known organism on Earth, the bacterium Pelagibacter ubique, subsists on dissolved nutrients in seawater (Morris et al. 2002). Yet, as mentioned, the discovery that marine bacteria can grow at significant rates in unenriched seawater was not made until the 1980s. Towards the end of the 1960s, experiments had been undertaken from which it was concluded, rather cryptically, that 'the standing concentration (steady-state or equilibrium) of organic substrates not utilized by bacterial oxidation may be characteristic for seawater as a suboptimal environment for microbial life' (Jannasch 1967, p. 271; 1968). This appears to have been considered at the time by most researchers as equivalent to saying that the substrate (i.e. seawater) is too dilute to support bacterial growth. This view was deeply entrenched; for example, A. F. Carlucci and S. Shimp were unable to publish their findings of isolated oligotrophic bacteria able to grow in unenriched seawater in mainstream scientific journals (A. F. Carlucci pers. comm.). Instead, they published the findings in conference proceedings (Carlucci \& Shimp 1974) and only later published the detailed findings (Carlucci et al. 1986). The 1960s finding of lack of growth in unenriched seawater may have been due to limitations of the cell count method (Jannasch \& Jones 1959).

\section{Bacterial growth in seawater}

SWC became an important model system for the study of bacterial growth in the pelagic ocean, for instance in efforts to determine bacterial growth rate in situ. Both methods using radioactive precursors to DNA and protein as well as growth cycle indicators such as frequency of dividing cells were calibrated using SWCs (Hagström et al. 1979, Fuhr- man \& Azam 1980, Kirchman et al. 1986). These new techniques to measure growth rate subsequently spurred extensive fieldwork to determine bacterial biomass turnover in different aquatic environments but with a somewhat disappointing outcome. It soon became clear that while separate estimates of growth rate, cell numbers and cell mass combined would provide the most accurate measure of bacterial production, integrated measures of production became the practical solution (Ducklow et al. 1986, Kirchman et al. 1986). Thus, the actual number of measurements of growth rate in situ for bacteria is few in the marine or other aquatic environments. In the following sections, we provide examples of growth rates for different bacterial isolates in artificial media or seawater. In particular, we examine different strategies of bacteria to proliferate in seawater and the effect of temperature as a major regulator of growth rate, as suggested from the 'Tara' Oceans expedition (Sunagawa et al. 2015). We finally discuss the current knowledge on how the diversity of isolated marine bacteria compares to the genomic diversity in the wild, i.e. natural microbial assemblages.

\section{SETTING THE SCENE}

A long-standing issue in marine microbiology relates to the ability of bacteria in nature to grow in laboratory pure cultures. Marine microbiologists until recently had assumed that $99.9 \%$ of the marine bacteria seen under the microscope are unculturable. The basis for this assumption is the low number of bacteria that are able to form colonies on a plate. This ignores the fact that some strains can form biofilm/ colonies or only grow as single cells (Simu \& Hagström 2004). Also, in situ physiological conditions of bacteria such as phage infection and possible resting stages might render some bacteria unculturable. Addressing the problem of low culturability (typically $0.1 \%$ ) requires a basic understanding of the in situ physiological state of bacteria and their survival strategies.

\section{Bacterial culturability}

Let us make some generalizations and examine a small volume of surface seawater. The sample we imagine we are looking at is fixed in formaldehyde, collected on a polycarbonate filter, stained with for example DAPI or SYBR Green ${ }^{\circledR}$ and viewed under an epifluorescence microscope. We will assume the 
field of view contains 100 bacteria-shaped objects. Further, we only consider chemoorganotrophic bacteria including methylotrophs and ask: What are these? What is their physiological state? What kind of interactions are they involved in? To keep track of the different life strategies, each strategy will be given a type number and a name. The names given to the numbered bacterial types/life strategies are added solely to help the reader by suggesting a stereotype. We are not trying to introduce a new classification. Instead, in the absence of valid phenotypic characterizations, we present nicknames that reflect the behavior of the described bacteria. After all, as more phenotypic characterization is done, we will eventually end up with a rainbow or a continuum of the expression of ecologically relevant phenotypes in varied environmental contexts.

\section{Solitary bacteria}

A large proportion of bacteria in the ocean are true oligotrophs, perhaps $>30 \%$, judging from counts based on genetic markers (Morris et al. 2002). They operate as single cells. These Type 1 'crumb picker' bacteria occupy habitats that support slow growth, and they tend to be small in size. Their modest appearance does not mean they are unimportant, since for example the most common bacterium on earth, Pelagibacter ubicutus, is included in this group (Morris et al. 2002, Rappé et al. 2002). However, they do not form biofilm or colonies, and therefore they have remained uncultured for a long time (Simu \& Hagström
2004). These true oligotrophic bacteria have evolved an optimal access to the substrate in a low-nutrient environment, presumably due to the presence of high-affinity, low-capacity substrate transport systems. These seemingly free-living bacteria represent a relatively new concept that is currently being integrated in the ecological narrative of the ocean (Table 1). Under oligotrophic conditions, a premium is presumably placed on the ability to successfully compete for resources with other bacteria as well as other members of the same species, and thus colony formation should be non-adaptive (Simu \& Hagström 2004).

In rich microenvironments, some bacteria can accomplish rapid growth as a result of behavioral and physiological adaptations to enhance their foraging success. These Type 2 'stalker' bacteria show growth characteristics close to the opportunists, optimally positioning themselves in relation to a substrate gradient and thus achieving rapid growth (Blackburn et al. 1998). Examples of the Type 2 strategy are seen in bacterial cells hovering around algal cells exuding organic matter (Stocker et al. 2008). In the case of a common diatom and a Sulfitobacter strain, metabolite and transcriptome analyses demonstrate that the bacterium promotes cell division of the diatom (Amin et al. 2015).

The frequent presence in marine metagenomes of bacterial genes coding for secretion mechanisms similar to those found in pathogenicity islands of animal and plant pathogens (Persson et al. 2009) suggests a life strategy expressed by Type 3 'killer' bacteria. The action of such Type 3 bacteria attacking and killing ageing algal cells towards the end of

Table 1. Brief history of the study of marine oligotrophic bacterioplankton. Major steps towards the integration of oligotrophic bacteria in the ecological narrative of the ocean

\begin{tabular}{|c|c|c|}
\hline Year & Author & Comment \\
\hline 1974 & $\begin{array}{l}\text { Carlucci \& Shimp (1974), } \\
\text { Carlucci et al. (1986) }\end{array}$ & $\begin{array}{l}\text { Isolated bacteria that grow in filtered seawater. Original } 1973 \text { finding initially rejected } \\
\text { for journal publication. }\end{array}$ \\
\hline 1979 & Kuznetsov et al. (1979) & $\begin{array}{l}\text { Defined oligotrophic bacteria as those that grow in media with a content of organic matter } \\
\text { of } 1 \text { to } 15 \mathrm{mg} \mathrm{Cl}^{-1} \text {. }\end{array}$ \\
\hline 1980 & Ishida et al. (1986) & Distinguished obligate and facultative oligotrophs. \\
\hline 1984 & Martin \& Mcleod (1984) & $\begin{array}{l}\text { Questioned the existence of } 2 \text { classes of bacteria based on their ability to grow on high } \\
\text { versus low concentrations of organic matter. }\end{array}$ \\
\hline 1984 & $\begin{array}{l}\text { Hagström et al. (1984), } \\
\text { Ammerman et al. (1984) }\end{array}$ & $\begin{array}{l}\text { Proved that free-living bacteria can grow in filtered seawater while using significant } \\
\text { amounts of dissolved amino acids. }\end{array}$ \\
\hline 1997 & Schut et al. (1997) & $\begin{array}{l}\text { Showed that free-living marine bacteria represent cells with low-nutrient-conditioned } \\
\text { phenotype, lacking flexibility and short-term adaptability. }\end{array}$ \\
\hline 2004 & Cho \& Giovannoni (2004) & Reported that uncultured and oligotrophic bacteria are the same. \\
\hline 2004 & Simu \& Hagström (2004) & $\begin{array}{l}\text { Suggested that oligotrophic bacteria are characterized in terms of behavior and choice } \\
\text { of life strategy, including nutrient preference. }\end{array}$ \\
\hline 2005 & Giovannoni et al. (2005) & $\begin{array}{l}\text { Pelagibacter sequenced. Suggested streamlined minigenome to be an adaptation to } \\
\text { oligotrophic life strategy. }\end{array}$ \\
\hline 2013 & Carini et al. (2013) & Demonstrated a defined medium for growth of Pelagibacter ubique. \\
\hline
\end{tabular}


blooms has been recorded repeatedly, as summarized in a review on algicidal bacteria in the sea by Mayali \& Azam (2004).

\section{Aggregating opportunists}

A small fraction of the bacteria are opportunistic, expressing strategies that render them culturable on rich media. Such Type 4 'fast handler' bacteria are found in a highly variable fraction (0.2 to $20 \%$ ) that nevertheless can respond quickly to organic input, e.g. attach to a colloid or a particle (Pinhassi et al. 1997). They grow rapidly to form microcolonies (cell aggregates) or biofilms, which means they have the ability to form colonies on agar plates. These bacteria are able to exploit organic matter in both dissolved and particulate form. Being able to react quickly and to outgrow the competition, they can form blooms in the wake of trophic events (Rehnstam et al. 1993). Thus, at times they are found in high abundance but relatively quickly return to low numbers (Fuhrman \& Hagström 2008). Usually, such bacteria can be grown on agar plates and in rich liquid cultures; because of the ease with which they can be isolated, these are the marine isolates most commonly deposited into culture collections. Surprisingly, there seems to exist a remarkable redundancy in substrate use among these bacteria, although taxonomic analysis shows considerable diversity among the opportunistic bacteria of the upper ocean (Pommier et al. 2007). No doubt, conditions do change over time and space, but on a given occasion removal of 1 or several bacterial types does not seem to reduce the ability to oxidize the organic matter present in the water (Sjöstedt et al. 2012). This seems to suggest that to consume the brunt of the DOC, no cooperation among these different bacterial strains seems essential, and a single strain might do the job equally well (Pedler et al. 2014).

While colony formation may seem like a simple and primary trait of bacteria, this is not the case (Davies et al. 1998, Li et al. 2002). The formation of colonies or biofilm requires an active process through quorum sensing. The flagella motor has to be shut down for the cells to aggregate, optimal cell-to-cell contact has to be established to allow good cellular communication and the production of extracellular enzymes must be directed towards the joint goal of the colony to exploit the organic substrate beneath the culture. Type 5, the 'fast builder' bacteria, have adopted a swarming behavior that can be seen as a special case of colony formation, but since the lateral invasion of the substrate surface is an actively coordinated pro- cess that requires quorum sensing, this behavior represents a life strategy of its own (Lindum et al. 1998).

\section{Dead or resting bacteria}

A confusing component in the microbial scenario is the significant fraction, often $>30 \%$, of most likely dead or inactive bacterial cells. These cells are not part of any specific life strategy but can cause conflicting results in various kinds of measurements. Under the light microscope, dead cells are indistinguishable from living cells but may consist of virusinfected, moribund cells or cell capsule remains ('ghosts'). The ghosts are distinguishable from live cells since the ghosts disappear when counter-stained (Zweifel \& Hagström 1995). Bacterial cells infected with lytic virus will fail to divide, yet they are biochemically active, and this may create results that are difficult to interpret. One example is the question of how to judge low-activity uptake of nucleotide precursors that can also be attributed to a resting state (Samo et al. 2014). The initial observation of bacterial ghosts has been investigated and questioned by several authors (Heissenberger et al. 1996, Luna et al. 2002, Jones \& Lennon 2010), and a reliable protocol to determine the fraction of live and functional cells is still lacking. Because of the renewed interest in phage therapy instead of treatments using antibiotics, the molecular tools used by phages to open the bacterial cell now start to shed light on the mechanisms involved in ghost formation (Haidinger et al. 2003, Letchumanan et al. 2016). These studies may help distinguish between phage-lysed ghost cells and intact cells including the actively growing cells in situ.

\section{ISOLATE IDENTITY AND THE SPECIES CONCEPT}

In the previous 2 sections, we have aimed to establish an overall setting for bacterial heterotrophic growth in the upper ocean, including the long-standing issue of how and why bacteria may be seen as culturable or otherwise. Before we turn to conclusions that may be drawn from studying bacterial isolates, we need to address the fundamental question of how to reconcile 2 images of the bacterial species concept. On the one hand, it is an empirically proven fact that taxonomically and functionally consistent strains of widely known bacteria such as Escherichia coli and Vibrio cholera can be isolated repeatedly 
(manuals found in any bacteriology textbook). On the other hand, a tremendous bacterial diversity can be anticipated from surveys based on molecular methods (Temperton \& Giovannoni 2012). In relation to the supposition that bacterial isolates might be useful as model bacteria, the question must therefore be raised as to how information from a single isolate may be of any relevance if the species richness is close to endless.

\section{Relevance of single genomes/isolates and $16 \mathrm{~S}$ rRNA}

To overcome the difficulty of cultivation, Swan et al. (2013) used a protocol for single amplified genomes (SAGs) to identify genomes from single bacterial cells. In their study, 56 SAGs were used to analyze genome streamlining and latitudinal divergence of planktonic bacteria. However, the same question of relevance to the natural assemblages may be raised towards the SAG studies as with bacterial isolates serving as model organisms. Can single genomes/ isolates represent wide taxa? In this context, the SAGs represent a biased selection, in the same way that isolation of bacteria on agar plates selects for opportunistic bacteria irrespective of their abundance. In the case of the SAGs, the relative abundance of the bacteria determines which cells preferentially become sequenced in the sample. Still, the larger question is not sampling bias per se but whether single genomes from either SAGs or bacterial isolates can be seen as representative model organisms. To answer this question, the following may be argued: (1) Based on DNA-DNA hybridization results, it is demonstrated that annually recurring bacterial blooms (Rehnstam et al. 1993) and seasonal succession of marine bacteria (Pinhassi \& Hagström 2000) can be recorded. Thus, DNA from single bacterial isolates can be used to find and quantify closely related DNA in environmental samples through DNA-DNA hybridization. (2) Similarly, global distribution of SAGrelated microorganisms (Swan et al. 2013) and insights into an abundant and uncultivated marine bacterial lineage SAR86 (Dupont et al. 2012) are both obtained using metagenomic fragment recruitment. Thus, genetic markers identified from a single-cell genome can be used to determine identity and abundance of defined taxa in metagenome samples using a phylogenomic analysis.

There are useful techniques available to identify and quantify bacterial taxa in the environment either directly or in silico from metagenomes. So, if identify- ing means recognizing and knowing the names of bacterial isolates, we can give a positive answer. This means microbial ecologists should be able to handle the species concept pragmatically, as we do with insect species or human pathogens that are the subjects of constant evolution. We need to recall that pathogenic bacteria can be recognized through isolation from the patient's body. Bacteriologists have thus learned to recover and name bacteria responsible for particular illnesses by experience and pragmatic means (Fraser et al. 2009). However, for this to happen in bacterial ecology, focus has to be turned away from bacterial phylogeny and be directed towards the identity of functional bacterial taxa. Then, we may see a totally different description of marine bacteria in the future.

\section{S rRNA species specificity}

For the past 3 decades, the majority of all phylogenetic analyses of bacterial clones or isolates have been based on sequencing the 16S rRNA gene. Because of its very specific function, this gene displays conserved regions, and it has become generally accepted that these regions carry some degree of specificity towards different kinds of bacteria. Since the suggestion by Woese that relationships between bacteria may be inferred from sequence similarity of the 16S rRNA, new bacteria, new habitats and global patterns of bacterial distribution have been described (Woese 1987, Fuhrman \& Hagström 2008). It is therefore an undisputed fact that $16 \mathrm{~S}$ rRNA-based studies in the sea have been very valuable. Yet, we may question parts of the original argument, since over the last few decades the effort to produce plausible lists of bacterial species for specific habitats has largely failed. Not only are we lacking a valid species definition (Fraser et al. 2009), but the whole taxonomic framework also suffers from undocumented assumptions. Experimental lateral transfer of intact 16S rRNA genes (Kitahara et al. 2012) and genetic engineering of specific fragments of the 16S rRNA gene between phylogenetically distant bacteria (Kannan et al. 2016) show fully functional ribosomes. This implies that over long periods of time, 16S rRNA genes could have been exchanged between core genomes. These results thus undermine the original assumption and add support to Kitahara et al. (2012), who conclude, 'The extreme ribosomal complexity is believed to be the basis for the species specificity in 16S rRNA, although solid experimental evidence is not available in this regard'. From this we realize and 
agree with Swan et al. (2013) that insufficient phylogenetic resolution might explain the difficulties in detecting consistent differentiation of bacterioplankton when performing small subunit rRNA gene surveys, for instance, along longitudinal gradients, although the more pronounced differences between polar and tropical bacterioplankton have been reported from such studies (Pommier et al. 2005, 2007, Ghiglione et al. 2012).

\section{BACTERIAL GROWTH RATE ADAPTATION TO TEMPERATURE - A CASE STUDY}

In the following section, the aim is to illustrate that ecophysiological insights can be gained by studying suitably selected bacterial isolates. For this, we use a 13 yr old and previously unpublished data set containing 55 bacterial isolates from 3 marine areas; this data set has been revisited, since it allows a comment on how the marine microbiology community might assimilate this information in thinking about the use of isolates in ecophysiology and biogeochemistry. Each isolate was grown at steady state in Zobell liquid media at 10 different temperatures from 5 to $50^{\circ} \mathrm{C}$, and the respective growth rates were recorded (see the Supplement at www.int-res.com/articles/suppl/a080 p015_supp.pdf for details of experimental conditions and statistical analyses). Based on these results, and in agreement with those discussed in the previous section from global surveys showing a latitudinal differentiation of marine bacterioplankton, the following framework can be formulated: The growth rate for different isolates, at their optimum temperature, depends on phylogenetic affiliation rather than geographic origin. Thus, temperature would drive annual species succession, as also suggested by results of culture-independent analysis from the 'Tara' expedition (Sunagawa et al. 2015). A major conclusion from the 'Tara' work is summarized in the following quote: 'Taken together our data suggest that geographic distance plays a subordinate role and reveals temperature to be the major environmental factor shaping taxonomic and functional microbial community composition in the photic open ocean'.

\section{Bacterial isolate identity}

The bacteria in our analysis included 2 Alphaproteobacteria, 4 Gammaproteobacteria and 6 Bacteroidetes from the Mediterranean Sea; 4 Alphaproteobacteria, 3 Gammaproteobacteria and 7
Bacteroidetes from the Southern California Bight; and 5 Alphaproteobacteria, 1 Gammaproteobacteria and 6 Bacteroidetes from the Baltic Sea. Details of these isolates are compiled in Table S1 in the Supplement. When comparing the identities of the isolates based on 16S rRNA sequence similarity generated in 2003 and 2016, a substantial discrepancy is apparent. It is clear that over time, identity defined as resemblance to other bacteria based on partial sequences of a single gene does not provide sufficient resolving power to go beyond phylum or subclass. However, the distribution of the bacterial isolates over a general phylogenetic tree is sufficient to allow us to determine that the isolates do not represent a closely related cluster (see Fig. S1 in the Supplement).

\section{Growth characteristics of selected opportunistic bacteria}

Each isolate demonstrated a characteristic temperature-to-growth rate relationship as exemplified in Fig. 1, showing a number of isolates from the Southern California Bight. Growth rate at optimum growth temperature was determined from the resulting growth curves, as well as minimum and maximum tempera-

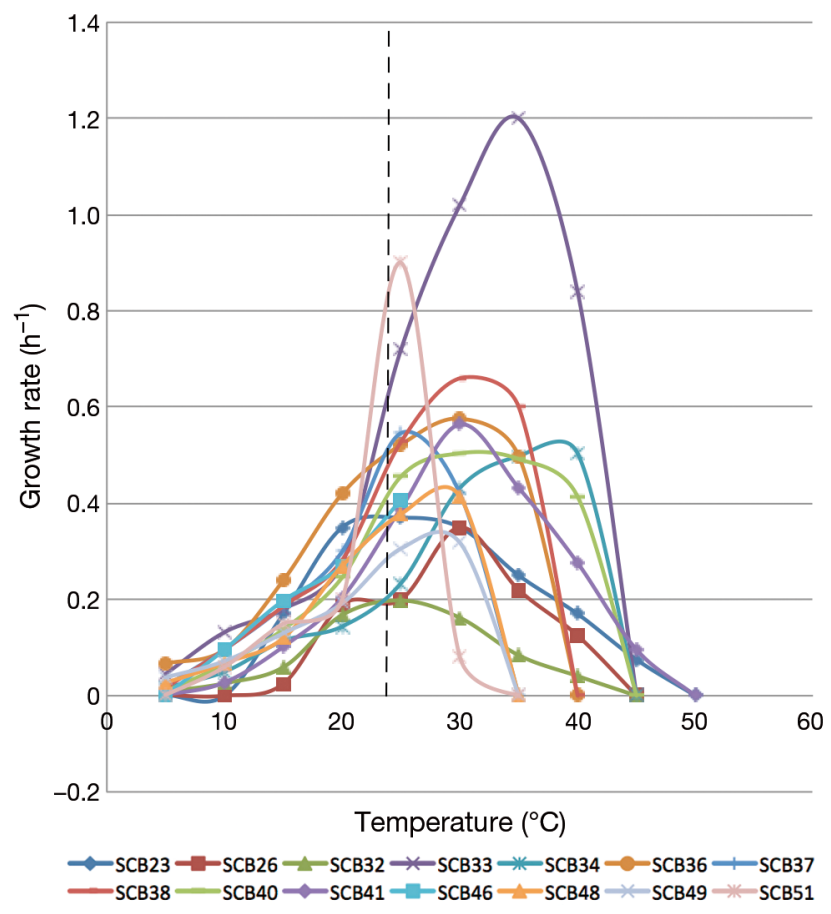

Fig. 1. Growth temperature plots for 14 bacterial isolates from the Southern California Bight (SCB) (for details of the isolates, see Table S1 in the Supplement at www.int-res.com/ articles/suppl/a080p015_supp.pdf). The dashed vertical line represents maximum surface water temperature 
tures for growth. Typically, growth rates at temperatures above the optimum temperature shape the curve into a steep downward slope. The results are summarized in Fig. 2, where the average growth rates of the isolates at each temperature are plotted for each of the 3 different bacterial divisions. The large variability in growth rate at higher temperature is caused by the different optima displayed by the isolates, causing the growth rate to drop within a wide upper range of temperatures (see Fig. 1). The growth rates were significantly related to growth temperature and taxonomic affiliation of the investigated strains

\section{A Growth rates}

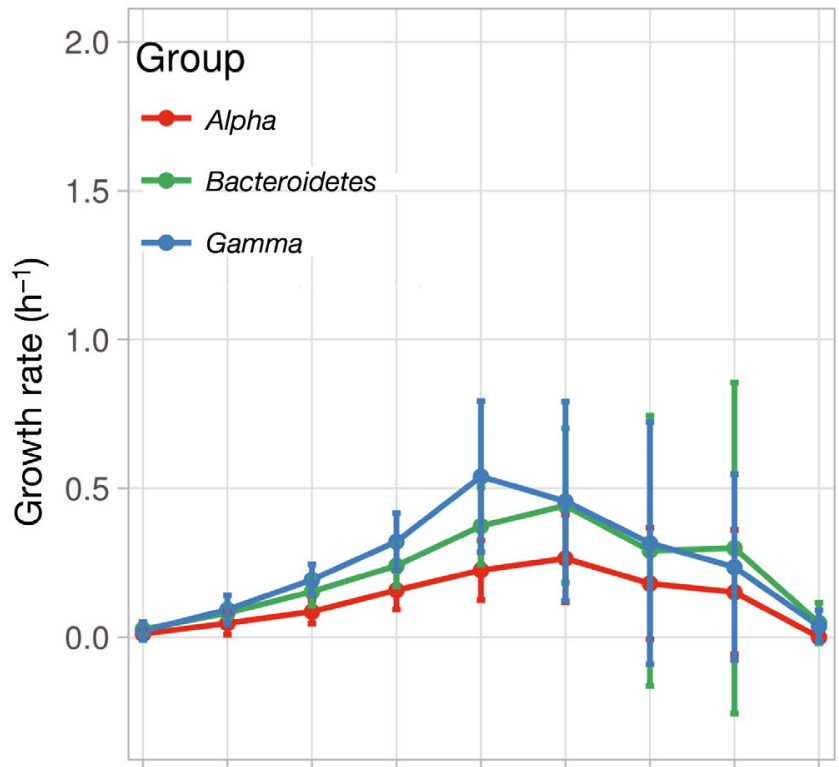

\section{Gamma}

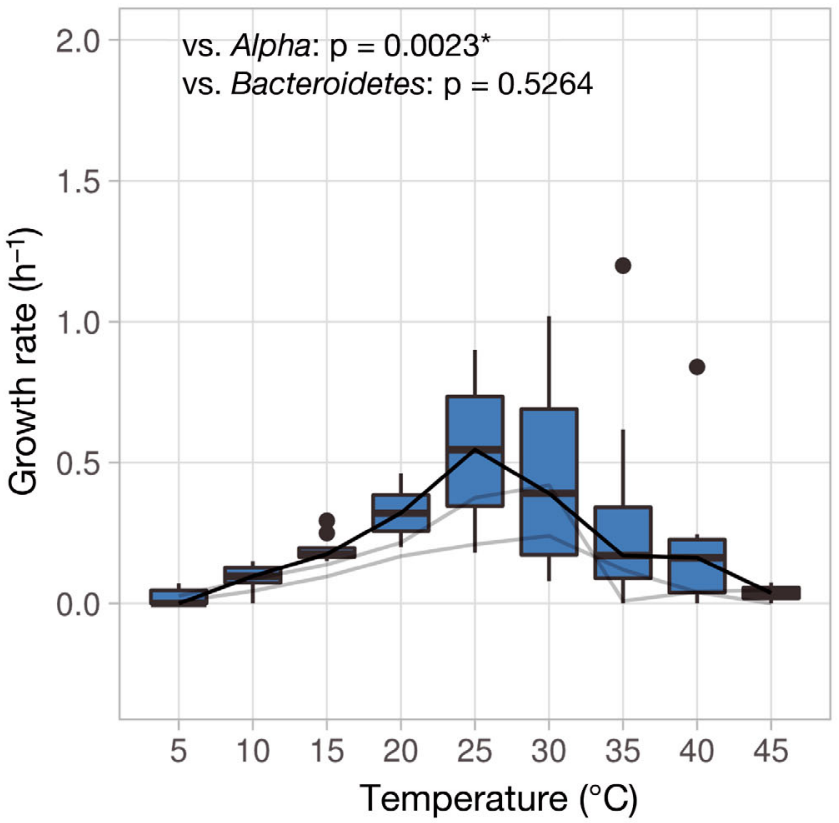

\section{B Alpha}

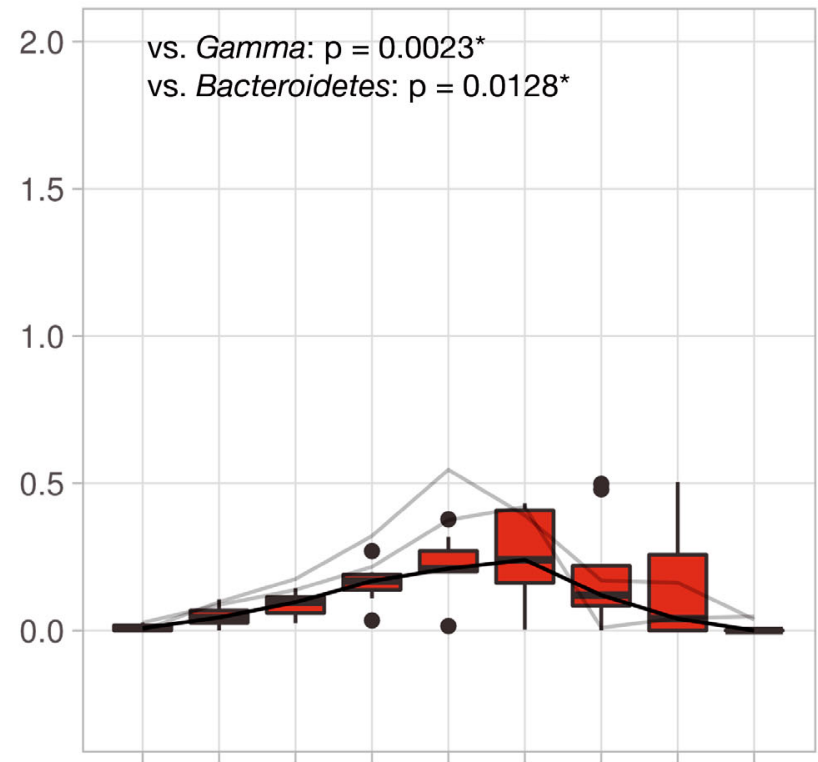

\section{Bacteroidetes}

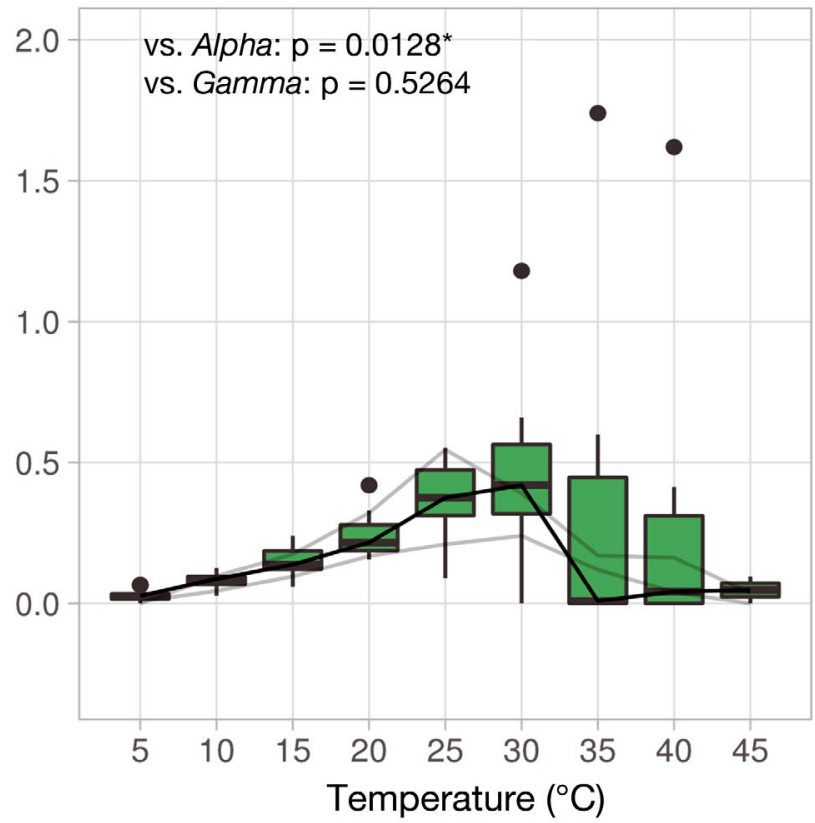

Fig. 2. (A) Mean growth rates divided after taxonomic affiliation of isolates at different temperatures; error bars represent SD. (B-D) Box plots showing growth rates of Alphaproteobacteria (red), Gammaproteobacteria (blue) and Bacteroidetes (green). Horizontal line inside the box represents the median, which is also connected by curves throughout the temperature range (line plots). Upper and lower margins of the boxes are the 75th (Q3) and 25th (Q1) percentiles; dots represent outliers defined as being less than $\mathrm{Q} 1-1.5 \times \mathrm{IQR}$ or greater than $\mathrm{Q} 3+1.5 \times \mathrm{IQR}_{;} \mathrm{IQR}=\mathrm{Q} 3-\mathrm{Q} 1$. IQR: interquartile range; $\mathrm{Q}$ : quartile 
$\left(p=5.9 \times 10^{-9}\right.$ and $p=7 \times 10^{-4}$, respectively). In contrast, growth rate was not related to geographical origin $(p=0.47)$. Grouping the strains by their taxonomic origin, the Alphaproteobacteria had a significantly lower growth rate than the Bacteroidetes $(\mathrm{p}=0.0128$, Tukey's HSD post hoc test) and the Gammaproteobacteria ( $\mathrm{p}=0.0023)$. In contrast, growth of Gammaproteobacteria was not significantly different from that of Bacteroidetes $(p=0.53)$. From these results, we find weak but statistically significant support for the hypothesis that major phylogenetic groups on average show different growth rates.

\section{Sampling sites and isolates}

The different sea areas chosen to isolate bacteria from are different in many aspects, but here 2 particular aspects are noted, temperature range and overall nutrient regimes. The brackish Baltic Sea is temperate, with water temperature ranging from 0 to $20^{\circ} \mathrm{C}$ over the year and with a salinity gradient from north to south of 3 to $10 \%$. Phosphorus limits growth in the north, while nitrogen limitation prevails in the south, i.e. in the Baltic proper (Zweifel et al. 1993). The northeastern Mediterranean Sea and the Southern California Bight, on the other hand, both exhibit similar salinity and temperature regimes, yet the nutrient status differs, the Mediterranean Sea being phosphorus limited and the Southern California Bight being mainly nitrogen limited (Fuhrman et al. 1988, Thingstad \& Rassoulzadegan 1995).

The Baltic strains showed an optimum growth temperature between 15 and $35^{\circ} \mathrm{C}$, with an average of 26 $\pm 6^{\circ} \mathrm{C}$ (SD) (Table 2). All strains could grow at $5^{\circ} \mathrm{C}$, and 2 strains had an optimum growth temperature $<20^{\circ} \mathrm{C}$ (Fig. 2). The growth rate at optimum growth temperature averaged $0.40 \mathrm{~h}^{-1}$. The isolates from the Mediterranean Sea had an optimum growth temperature between 30 and $35^{\circ} \mathrm{C}$, with an average of $28 \pm$ $4^{\circ} \mathrm{C}$. Three of 7 strains did not grow below $10^{\circ} \mathrm{C}$. The growth rate at optimum growth temperature averaged $0.50 \mathrm{~h}^{-1}$. Among the isolates from the Southern California Bight, optimum temperature for growth varied between 25 and $40^{\circ} \mathrm{C}$, with an average of $29 \pm$ $4^{\circ} \mathrm{C}$ (Table 2). Fifteen of 19 strains were capable of growth at $5^{\circ} \mathrm{C}$, while 3 strains did not grow below $10^{\circ} \mathrm{C}$, and 1 strain did not grow below $15^{\circ} \mathrm{C}$. The growth rate at optimum temperature for growth averaged $0.54 \mathrm{~h}^{-1}$. Bacteria able to grow at $5^{\circ} \mathrm{C}$ were only found among the Baltic Sea isolates, and 2 psychrophiles (bacteria with an optimum growth temperature $<20^{\circ} \mathrm{C}$ ) were found among these isolates.
Table 2. Average phenotypic characteristics of isolates compared between affiliation and origin. ${ }^{*}$ Significantly higher than Alphaproteobacteria ( $\mathrm{p}<0.05)$. Alpha: Alphaproteobacteria; Bact: Bacteroidetes; Gamma: Gammaproteobacteria; BAL: Baltic Sea; MED: Mediterranean Sea, SCB: Southern California Bight; $\mathrm{T}_{\text {opt }}$ : temperature optimum

\begin{tabular}{|c|c|c|c|c|c|c|}
\hline \multirow{2}{*}{$\begin{array}{l}\text { Phenotypic } \\
\text { test }\end{array}$} & \multicolumn{3}{|c|}{$\longrightarrow$ Affiliation $\longrightarrow$} & \multicolumn{3}{|c|}{ Origin } \\
\hline & Alpha & Bact & Gamma & BAL & MED & SCB \\
\hline $\mathrm{T}_{\text {opt }}\left({ }^{\circ} \mathrm{C}\right)$ & 27.9 & 27.9 & 26.9 & 25.7 & 28.1 & 29.1 \\
\hline $\begin{array}{l}\text { Growth rate } \\
\text { at } T_{\text {opt }}\left(\mathrm{h}^{-1}\right)\end{array}$ & 0.30 & $0.50^{*}$ & $0.64^{*}$ & 0.40 & 0.50 & 0.54 \\
\hline Motility (\%) & 82 & 37 & 75 & 83 & 50 & 43 \\
\hline
\end{tabular}

This suggests adaptation to the temperature environment from which the bacteria were isolated. However, growth rates did not differ significantly $(\mathrm{p}=$ 0.46 to $p=0.95,2$-way ANOVA and Tukey HSD post hoc test) between isolates from the 3 different sea areas. In nature, bacteria will not experience the optimum growth temperature, since this temperature averaged $30^{\circ} \mathrm{C}$ for all isolates tested. Thus, the isolated marine bacterioplankton in this study usually grow at temperatures $>10^{\circ} \mathrm{C}$ below their optimum temperature for growth.

\section{Motility}

In an attempt to find further characteristics between different groups of isolates, motility was recorded. While it seems the true oligotrophs are nonmotile, a total of $58 \%$ of the tested opportunistic bacteria were motile (Table 2). Different swimming modes were visually recorded and ranged from a comparably slow pace to intense swarming. In an earlier study of many of the same bacterial isolates as in this study, Alphaproteobacteria were found to have the slowest swimming speed (Johansen et al. 2002). Of the 3 major divisions of bacteria studied, the Alpha- and Gammaproteobacteria included a higher number of motile bacteria (82 and $75 \%$, respectively) than the Bacteroidetes ( $37 \%)$. The isolates from the Baltic included a higher number of motile bacteria (83\%) than those from the Mediterranean Sea and Southern California Bight (50 and $43 \%$, respectively).

\section{CONSEQUENCES AND SUGGESTIONS}

Seawater may seem to be a poor substrate, and compared to a rich broth it is certainly dilute; how- 
ever, the quality of the substrate, that is, the proportions of macromolecules to monomers and organic to inorganic ratios, is much the same in seawater as in a broth. Thus, having an efficient uptake system is what determines whether a bacterial strain can grow in seawater, and the cell abundance, of course, can never be high.

\section{In situ growth rate versus culture data and life strategy}

The growth rates given in Table 2 for the opportunistic bacteria were recorded at temperature optimum for the respective strain, and to compare these rates to those of the oligotrophs grown at $15^{\circ} \mathrm{C}$ (Table 3), a correction is needed. From the curves in Fig. 2, the range of growth rate at $15^{\circ} \mathrm{C}$ can be seen to be between 0.09 and $0.20 \mathrm{~h}^{-1}$ for the isolates of the opportunistic bacteria. If that is compared to growth rates of around $0.015 \mathrm{~h}^{-1}$ for the oligotrophs (Table 3, growth rate $\mathrm{d}^{-1}$ ), the former are more than 10 times faster than the oligotrophs. These group-specific traits may be important for the establishment and succession of bacterioplankton (as discussed in the following sections) in relation to properties of the core genome defining a bacterial species.

Comparing the growth rates of virus-free bacterial isolates in cultures, oligotrophic bacteria on average grew $>10$ times slower than most opportunistic bacteria (Fig. 2, Table 3). The real question, however, is what this difference in growth rate might be in the natural environment. For the sake of argument, we will claim that the oligotrophic strains in Table 3 grow in seawater, although the SAR11 cultures were amended with mineral nutrients. After all the talk earlier in this paper concerning SWC, it may come as an anticlimax that very few identified opportunistic bacterial isolates have been grown in seawater. In fact, the Alteromonas strain grown by Pedler et al. (2014) and Dokdonia sp. strain MED134 (Gómez-Consarnau et al. 2007), together with the
SAR11 isolates, are the only published examples we could find. There exist, however, quite a few published data sets of seawater cultures from chemostats and batch cultures, although these are all mixed cultures. The Alteromonas and Dokdonia both grew at about $0.03 \mathrm{~h}^{-1}$, which is twice as fast as the common oligotrophs $\left(0.015 \mathrm{~h}^{-1}\right)$. In the seawater chemostats with mixed marine bacteria inoculates, the maximum recorded and published turnover rate is $0.11 \mathrm{~h}^{-1}$ (Hagström et al. 1984), thus at the lower range of the growth rate of the opportunist strains in this paper. Still, if we consider that, in addition to the flow rate removing cells from the chemostat, an internal mortality factor caused by phages has to be compensated for, we can estimate the actual growth rate in the chemostat. From model simulation of a data set obtained in a multistage seawater chemostat, the true growth rate was shown to be 2 to 10 times higher for the non-infected cells depending on the turnover rate in the chemostat (Blackburn et al. 1996, Zweifel et al. 1996).

In terms of bacterial production, this means that while oligotrophic bacteria are very abundant in surface waters, opportunistic bacteria should easily outgrow them, and as their cell volume can be $>10$ times larger than the oligotrophic bacteria, this ability becomes even more pronounced in production terms. In this regard, Pedler et al. (2014) demonstrated complete removal of the labile DOC in coastal surface seawater by a single opportunistic taxon.

\section{Generating microdiversity in real time}

Bacteriophage resistance is a summary term for a large number of molecular strategies where the bacteria are able to fend off the attacks by viruses to some degree (Labrie et al. 2010). In every case, an evolutionary arms race of varying intensity can be expected to result in the development of microdiversity. In particular, the interaction between the outer membrane proteins and phage attachment

Table 3. Growth rate of oligotrophic marine isolates. SWC: seawater culture; ND: no data

\begin{tabular}{|c|c|c|c|c|c|c|}
\hline \multirow{2}{*}{ Isolate } & \multirow[t]{2}{*}{ Accession no. } & \multirow{2}{*}{$\begin{array}{l}\text { Division } \\
\text { Source }\end{array}$} & \multicolumn{3}{|c|}{ - Growth rate $\left(\mathrm{d}^{-1}\right)$} & \multirow[t]{2}{*}{ Citation } \\
\hline & & & $\begin{array}{l}\text { SWC } \\
15^{\circ} \mathrm{C}\end{array}$ & $\begin{array}{c}\text { Rich media } \\
\text { Zobell }\end{array}$ & Solid surface & \\
\hline BAL58 & AY317112 & Betaproteobacteria & 0.52 & No growth & 0.27 & Simu \& Hagström (2004) \\
\hline BAL59 & AY317114 & Betaproteobacteria & 0.47 & 0.19 & 0.36 & Simu \& Hagström (2004) \\
\hline SKA48 & AY317115 & Alphaproteobacteria & 0.40 & No growth & 0.01 & Simu \& Hagström (2004) \\
\hline SAR 11 & HTCC 1002 & Alphaproteobacteria & $0.40-0.58$ & ND & ND & Rappé et al. (2002) \\
\hline
\end{tabular}


may serve as a rapidly evolving battlefield. The outer membrane of Gram-negative bacteria contains several general porins, various high-affinity substrate receptors and different iron complexes, which are used as phage receptors. Further examples are the TonB and TolA proteins, which are anchored to the inner membrane but span the periplasm and as such are important for infection by many phages (Guttman et al. 2005). Thingstad et al. (2015) have proposed a model to account for phage resistance and the number of bacterial taxa in a given habitat. Based on their model, we visualize the virus host interaction in a closed substrate controlled space as follows: Imagine an initial number of cells of a bacterial species that utilizes the available food source in full. A corresponding bacteriophage would then be able to infect and kill a large fraction of these cells. This will in all likelihood select for a modified bacterium (a strain) resistant to the phage, but with resistance follows a slight penalty in growth rate that does not prevent utilization of the food source not used by the original unmodified species. In this manner, new strains of both the host and the phage can be selected for, in an ongoing arms race, until there is no more room (substrate resource) for hosts to grow and produce large enough phage populations that can infect sensitive hosts. An alternative restriction to further host strains is if growth rate due to cost of resistance for new strains has been reduced below the bacterial clearance rate exerted by the protozoa. However, at any time during the process, a new species equipped with a different core genome can be introduced into the habitat and, if conditions like temperature have changed, may compete successfully for the available resources, since, on the scale of bacterial presence, conditions constantly change. This is due to diurnal variation, zooplankton activity and so on. Thus, the arms race within each bacterial species will rarely come to an end; instead, an arena with a diverse bacterial community is generated containing high viral numbers and many susceptible hosts.

\section{Marine isolates representing core genomes}

The results in Tables $2 \& 3$ originate from growth experiments involving a long list of marine isolates (Table S1 in the Supplement). To understand the integration of these isolates in the natural environment, we suggest that the pan-genome concept of Tettelin et al. (2005) be adopted. The pan-genome includes the core genome-containing genes present in all strains, where in addition certain strains harbor unique but dispensable genes (Medini et al. 2005). In seawater, a successful bacterial species carries a core genome well suited for the particular habitat, which is demonstrated by fast growth. To flourish, the species must have the correct temperature optimum, a shape and size suitable for osmotrophic life and the ability to display a correct salinity preference; to do even better, it should have acquired additional traits that match the existing local conditions. The core genome has an organized structure evolved through having experienced eons of habitat fluctuations (Rocha 2008, Caro-Quintero \& Konstantinidis 2012). With this view, the core genome may be regarded as the evolutionary solution to the least unfavorable gene composition in relation to environmental change. The difference in growth characteristics seen between the different groups of bacteria in Table 2 may thus be an observable example of this overarching evolutionary outcome.

\section{CLOSING REMARKS}

While large numbers of bacterial strains have had their DNA sequenced partly or as whole-genome projects, no general information about the organisms can be found. Compared to animals and plants, where the species names carry information gathered over hundreds of years, most bacteria, except perhaps pathogenic strains, are totally anonymous. To advance the field of marine microbiology, we therefore rally behind the strategy of Browne et al. (2016). These authors, working on the human microbiota, suggest that when culturing targeted phenotypes and linking whole-genome sequencing with phylogenetic analysis and computational modeling, the results will demonstrate a substantial proportion of bacteria in different habitats to be culturable. The extensive work by Stephen Giovannoni and his group on Pelagibacter ubique serves as an excellent example of how to isolate, grow and investigate a new bacterium (Giovannoni \& Stingl 2007, Carini et al. 2013). To move microbiology forward, we conclude that physiological data need to be included into molecular databases, and other recent papers have also highlighted this same need from different perspectives (Garcia 2016, Salcher \& Šimek 2016). Examples of prokaryote behavior that can be recorded easily are growth strategies and motility. In the future, we believe that generating ecological information from cultured bacteria will revitalize marine microbiology. 
Acknowledgements. This paper is based on a keynote address delivered by $\AA$. Hagström at the EMBO Symposium on Aquatic Microbial Ecology (SAME) 14 meeting held in Uppsala, Sweden, 23-28 August 2015. This work was supported by the BLUEPRINT project, funded by the European Community's Seventh Framework Programme (FP/20072013) under implementation agreement no. R\&I/I3/2012/ BONUS made with BONUS, the joint Baltic Sea research and development programme.

\section{LITERATURE CITED}

Amin SA, Hmelo LR, Van Tol HM, Durham BP and others (2015) Interaction and signalling between a cosmopolitan phytoplankton and associated bacteria. Nature 522: 98-101

Ammerman JW, Fuhrman JA, Hagström ^̊, Azam F (1984) Bacterioplankton growth in seawater: I. Growth kinetics and cellular characteristics in seawater cultures. Mar Ecol Prog Ser 18:31-39

* Blackburn N, Zweifel UL, Hagström Å (1996) Cycling of marine dissolved organic matter. II. A model analysis. Aquat Microb Ecol 11:79-90

Blackburn N, Fenchel T, Mitchell J (1998) Microscale nutrient patches in planktonic habitats shown by chemotactic bacteria. Science 282: 2254-2256

Browne HP, Forster SC, Anonye BO, Kumar N and others (2016) Culturing of 'unculturable' human microbiota reveals novel taxa and extensive sporulation. Nature 533: 543-546

Button DK, Schut F, Quang P, Martin R, Robertson BR (1993) Viability and isolation of marine bacteria by dilution culture: theory, procedures, and initial results. Appl Environ Microbiol 59:881-891

Carini P, Steindler L, Beszteri S, Giovannoni SJ (2013) Nutrient requirements for growth of the extreme oligotroph 'Candidatus Pelagibacter ubique' HTCC1062 on a defined medium. ISME J 7:592-602

Carlucci AF, Shimp SL (1974) Isolation and growth of marine bacterium in low concentrations of substrate. In: Colwell RR, Morita RY (eds) Effect of the ocean environment on microbial activities. University Press, Baltimore, MD

Carlucci AF, Shimp SL, Craven DB (1986) Growth characteristics of low-nutrient bacteria from the north-east and central Pacific Ocean. FEMS Microbiol Ecol 38: $1-10$

Caro-Quintero A, Konstantinidis KT (2012) Bacterial species may exist, metagenomics reveal. Environ Microbiol 14: 347-355

Cho JC, Giovannoni SJ (2004) Cultivation and growth characteristics of a diverse group of oligotrophic marine Gammaproteobacteria. Appl Environ Microbiol 70: 432-440

Davies DG, Parsek MR, Pearson JP, Iglewski BH, Costerton JW, Greenberg EP (1998) The involvement of cell-to-cell signals in the development of a bacterial biofilm. Science 280:295-298

₹ Ducklow HW, Purdie DA, Williams PJ, Davies JM (1986) Bacterioplankton: a sink for carbon in a coastal marine plankton community. Science 232:865-867

Dupont CL, Rusch DB, Yooseph S, Lombardo MJ and others (2012) Genomic insights to SAR86, an abundant and uncultivated marine bacterial lineage. ISME J 6:1186-1199
Fraser C, Alm EJ, Polz MF, Spratt BG, Hanage WP (2009) The bacterial species challenge: making sense of genetic and ecological diversity. Science 323:741-746

*Fuhrman JA, Azam F (1980) Bacterioplankton secondary production estimates for coastal waters of British Columbia, Antarctica, and California. Appl Environ Microbiol 39:1085-1095

Fuhrman J, Hagström ^ (2008) Bacterial community structure and its patterns. In: David K (ed) Microbial ecology of the oceans. Wiley, New York, NY

Fuhrman JA, Horrigan SG, Capone DG (1988) Use of ${ }^{13} \mathrm{~N}$ as tracer for bacterial and algal uptake of ammonium from seawater. Mar Ecol Prog Ser 45:271-278

Garcia SL (2016) Mixed cultures as model communities: hunting for ubiquitous microorganisms, their partners, and interactions. Aquat Microb Ecol 77:79-85

* Ghiglione JF, Galand PE, Pommier T, Pedrós-Alió C and others (2012) Pole-to-pole biogeography of surface and deep marine bacterial communities. Proc Natl Acad Sci USA 109:17633-17638

KGiovannoni S, Stingl U (2007) The importance of culturing bacterioplankton in the 'omics' age. Nat Rev Microbiol 5: 820-826

*Giovannoni SJ, Tripp HJ, Givan S, Podar M and others (2005) Genome streamlining in a cosmopolitan oceanic bacterium. Science 309:1242-1245

*Gómez-Consarnau L, Gonzalez JM, Coll-Llado M, Gourdon $P$ and others (2007) Light stimulates growth of proteorhodopsin-containing marine Flavobacteria. Nature 445:210-213

Guttman B, Raya P, Kutter E (2005) Basic phage biology. In: Kutter E, Sulakvelidze A (eds) Bacteriophages biology and applications. CRC Press, Boca Raton, FL

* Hagström Å, Larsson U, Hörstedt P, Normark S (1979) Frequency of dividing cells, a new approach to the determination of bacterial growth rates in aquatic environments. Appl Environ Microbiol 37:805-812

*Hagström A, Ammerman JW, Henrichs S, Azam F (1984) Bacterioplankton growth in seawater: II. Organic matter utilization during steady-state growth in seawater cultures. Mar Ecol Prog Ser 18:41-48

*Haidinger W, Mayr UB, Szostak MP, Resch S, Lubitz W (2003) Escherichia coli ghost production by expression of lysis gene $E$ and staphylococcal nuclease. Appl Environ Microbiol 69:6106-6113

*Heissenberger A, Leppard GG, Herndl GJ (1996) Relationship between the intracellular integrity and the morphology of the capsular envelope in attached and free-living marine bacteria. Appl Environ Microbiol 62:4521-4528

Ishida Y, Eguchi M, Kadota H (1986) Existence of obligately oligotrophic bacteria as a dominant population in the South China Sea and the West Pacific Ocean. Mar Ecol Prog Ser 30:197-203

* Jannasch HW (1967) Growth of marine bacteria at limiting concentrations of organic carbon in seawater. Limnol Oceanogr 12:264-271

Jannasch HW (1968) Growth characteristics of heterotrophic bacteria in seawater. J Bacteriol 95:722-723

Jannasch HW (1979) Microbial ecology of aquatic low nutrient habitats. In: Shilo M (ed) Strategies of microbial life in extreme environments. Verlag Chemie, Weinheim, p 243-260

Jannasch HW, Jones GE (1959) Bacterial populations in sea water as determined by different methods of enumeration. Limnol Oceanogr 4:128-139 
Johansen JE, Pinhassi J, Blackburn N, Zweifel UL, Hagström Å (2002) Variability in motility characteristics among marine bacteria. Aquat Microb Ecol 28:229-237

Jones SE, Lennon JT (2010) Dormancy contributes to the maintenance of microbial diversity. Proc Natl Acad Sci USA 107:5881-5886

Kannan K, Tsvetanova B, Chuang RY, Noskov VN and others (2016) One step engineering of the small-subunit ribosomal RNA using CRISPR/Cas9. Sci Rep 6:30714

Kirchman DL, Newell SY, Hodson RE (1986) Incorporation versus biosynthesis of leucine: implications for measuring rates of protein synthesis and biomass production by bacteria in marine systems. Mar Ecol Prog Ser 32: 47-59

Kitahara K, Yasutake Y, Miyazaki K (2012) Mutational robustness of $16 \mathrm{~S}$ ribosomal RNA, shown by experimental horizontal gene transfer in Escherichia coli. Proc Natl Acad Sci USA 109:19220-19225

Kuznetsov SI, Dubinina GA, Lapteva NA (1979) Biology of oligotrophic bacteria. Annu Rev Microbiol 33:377-387

Kabrie SJ, Samson JE, Moineau S (2010) Bacteriophage resistance mechanisms. Nat Rev Microbiol 8:317-327

* Letchumanan V, Chan KG, Pusparajah P, Saokaew S and others (2016) Insights into bacteriophage application in controlling Vibrio species. Front Microbiol 7:1114

Li WKW, Dickie PM (1985) Growth of bacteria in seawater filtered through $0.2 \mu \mathrm{m}$ Nuclepore membranes: implications for dilution experiments. Mar Ecol Prog Ser 26: 245-252

Li YH, Tang N, Aspiras MB, Lau PCY, Lee JH, Ellen RP, Cvitkovitch DG (2002) A quorum-sensing signaling system essential for genetic competence in Streptococcus mutans is involved in biofilm formation. J Bacteriol 184: 2699-2708

* Lindum PW, Christophersen AC, Eberl L, Molin S, Givskov M (1998) N-Acyl-L-homoserine lactone autoinducers control production of an extracellular lipopeptide biosurfactant required for swarming motility of Serratia liquefaciens MG1. J Bacteriol 180:6384-6388

* Luna GM, Manini E, Danovaro R (2002) Large fraction of dead and inactive bacteria in coastal marine sediments: comparison of protocols for determination and ecological significance. Appl Environ Microbiol 68:3509-3513

Martin P, Macleod RA (1984) Observations on the distinction between oligotrophic and eutrophic marine bacteria. Appl Environ Microbiol 47:1017-1022

Mayali X, Azam F (2004) Algicidal bacteria in the sea and their impact on algal blooms. J Eukaryot Microbiol 51: 139-144

* Medini D, Donati C, Tettelin H, Masignani V, Rappuoli R (2005) The microbial pan-genome. Curr Opin Genet Dev 15:589-594

* Morris RM, Rappé MS, Connon SA, Vergin KL, Siebold WA, Carlson CA, Giovannoni SJ (2002) SAR11 clade dominates ocean surface bacterioplankton communities. Nature 420:806-810

* Pedler BE, Aluwihare LI, Azam F (2014) Single bacterial strain capable of significant contribution to carbon cycling in the surface ocean. Proc Natl Acad Sci USA 111:7202-7207

Persson OP, Pinhassi J, Riemann L, Marklund BI and others (2009) High abundance of virulence gene homologues in marine bacteria. Environ Microbiol 11:1348-1357

Pinhassi J, Hagström $\AA$ (2000) Seasonal succession in marine bacterioplankton. Aquat Microb Ecol 21:245-256
Pinhassi J, Zweifel UL, Hagström Å (1997) Dominant marine bacterioplankton species found among colony-forming bacteria. Appl Environ Microbiol 63:3359-3366

* Pommier T, Pinhassi J, Hagström Å (2005) Biogeographic analysis of ribosomal RNA clusters from marine bacterioplankton. Aquat Microb Ecol 41:79-89

* Pommier T, Canback B, Riemann L, Bostrom KH and others (2007) Global patterns of diversity and community structure in marine bacterioplankton. Mol Ecol 16: $867-880$

* Rappé MS, Connon SA, Vergin KL, Giovannoni SJ (2002) Cultivation of the ubiquitous SAR11 marine bacterioplankton clade. Nature 418:630-633

* Rehnstam AS, Bäckman S, Smith DC, Azam F, Hagström Å (1993) Blooms of sequence-specific culturable bacteria in the sea. FEMS Microbiol Ecol 102:161-166

* Rocha EPC (2008) The organization of the bacterial genome. Annu Rev Genet 42:211-233

Salcher MM, Šimek K (2016) Isolation and cultivation of planktonic freshwater microbes is essential for a comprehensive understanding of their ecology. Aquat Microb Ecol 77:183-196

Samo TJ, Smriga S, Malfatti F, Sherwood BP, Azam F (2014) Broad distribution and high proportion of protein synthesis active marine bacteria revealed by click chemistry at the single cell level. Front Mar Sci 1:48

* Schut F, Prins RA, Gottschal JC (1997) Oligotrophy and pelagic marine bacteria: facts and fiction. Aquat Microb Ecol 12:177-202

* Simu K, Hagström Å (2004) Oligotrophic bacterioplankton with a novel single-cell life strategy. Appl Environ Microbiol 70:2445-2451

* Simu K, Holmfeldt K, Zweifel UL, Hagström Å (2005) Culturability and coexistence of colony-forming and single-cell marine bacterioplankton. Appl Environ Microbiol 71: 4793-4800

* Sjöstedt J, Koch-Schmidt P, Pontarp M, Canbäck B and others (2012) Recruitment of members from the rare biosphere of marine bacterioplankton communities after an environmental disturbance. Appl Environ Microbiol 78: 1361-1369

* Stocker R, Seymour JR, Samadani A, Hunt DE, Polz MF (2008) Rapid chemotactic response enables marine bacteria to exploit ephemeral microscale nutrient patches. Proc Natl Acad Sci USA 105:4209-4214

* Sunagawa S, Coelho LP, Chaffron S, Kultima JR and others (2015) Ocean plankton. Structure and function of the global ocean microbiome. Science 348:1261359

* Swan BK, Tupper B, Sczyrba A, Lauro FM and others (2013) Prevalent genome streamlining and latitudinal divergence of planktonic bacteria in the surface ocean. Proc Natl Acad Sci USA 110:11463-11468

* Temperton B, Giovannoni SJ (2012) Metagenomics: microbial diversity through a scratched lens. Curr Opin Microbiol 15:605-612

* Tettelin H, Masignani V, Cieslewicz MJ, Donati C and others (2005) Genome analysis of multiple pathogenic isolates of Streptococcus agalactiae: implications for the microbial 'pan-genome'. Proc Natl Acad Sci USA 102: 13950-13955

* Thingstad TF, Rassoulzadegan F (1995) Nutrient limitations, microbial food webs, and 'biological C-pumps': suggested interactions in a P-limited Mediterranean. Mar Ecol Prog Ser 117:299-306

* Thingstad TF, Pree B, Giske J, Våge S (2015) What differ- 
ence does it make if viruses are strain-, rather than species-specific? Front Microbiol 6:320

Woese CR (1987) Bacterial evolution. Microbiol Rev 51: 221-271

Zweifel UL, Hagström Å (1995) Total counts of marine bacteria include a large fraction of non-nucleoid-containing bacteria (ghosts). Appl Environ Microbiol 61:2180-2185

Editorial responsibility: Paul del Giorgio,

Montreal, Quebec, Canada
Z Zweifel UL, Norrman B, Hagström Å (1993) Consumption of dissolved organic carbon by marine bacteria and demand for inorganic nutrients. Mar Ecol Prog Ser 101: 23-32

Zweifel UL, Blackburn N, Hagström A (1996) Cycling of marine dissolved organic matter. I. An experimental system. Aquat Microb Ecol 11:65-77

Submitted: November 17, 2016; Accepted: May 22, 2017

Proofs received from author(s): August 4, 2017 